\title{
Use Of Earnings Information For Stock Pricing In Different Market Cycles: The Effect Of Discretionary Accruals
}

Alireza Daneshfar, Ph.D. University of New Haven, USA Mohammad J. Saei, M.S., Ferdosi University, Iran

\begin{abstract}
This study examines the association between stock prices and discretionary accruals in different stock market cycles and presents evidence about the discrepancy in prior research that investors were able to identify earnings management in some cases, but not in some other cases. We argue that investors' reaction to the true nature of EPS changes may be different in different market cycles. We suggests that investors pay less attention to the nature of EPS changes in an optimistic cycle, and are more critical in neutral and pessimistic cycles. Therefore, investors are more likely to detect and count for any earnings management in a neutral or pessimistic cycle than in an optimistic cycle. Using the U.S. quarterly data from July 01, 1997 to June 29, 2001, three market cycles were identified: optimistic, neutral and pessimistic. The test results indicated that the association between discretionary accruals and abnormal stock returns were insignificant in the neutral market cycle, significant and positive in the optimistic cycle and significant and negative in the pessimistic cycle. These findings indicate that investors tend to ignore the incomeincreasing effect of discretionary accruals on EPS changes in an optimistic market. The finding suggests that a more delegate and technical analysis of EPS changes is required when earnings information is used for stock pricing. It also suggests that a consideration of market cycle effect on investors' use of EPS could improve the earnings-based ratio analysis. The findings propose that researchers interested in investigating the association between stock prices and earnings management should control for the effect of the market cycle during which their samples are drawn.
\end{abstract}

\section{INTRODUCTION}

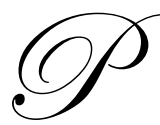

rior research on earnings management's ability to push up stock prices in several situations has been mixed at best. Some studies have found that earnings management can push up stock prices (see, e.g.Yongtae and Myung, 2005; Fischer and Stocken, 2004; Abarbanell and Lehavy, 2003). To the contrary, other studies have found that investors were able to find about the true nature of changes in earnings per share (EPS) and discounted the effect of opportunistic earnings management in the stock prices (e.g. Siew, Welch and Wong, 1998; Rangan, 1998; Marquardt and Wiedman, 2004; Aharony, Lee and Wong, 2000). The interesting question that emerges is why investors were able to identify the earnings management in some cases, but not in others. This study addresses this issue by investigating the effect of stock market cycles on investors' use of EPS information. As earnings management often take place through the inflation of discretionary accruals, we investigate whether different market cycles affect investors' reaction to discretionary accruals. We define market cycles as optimistic, neutral and pessimistic. Optimistic market cycle is referred to the situation in which investors are optimistic about future economy and stock prices are increasing in general. Neutral market cycle refers to the situation when there is no emotional market environment and investors evaluate the economic information including EPS changes analytically. Pessimistic market cycle exists when a price reevaluation began across the board and current prices are seen too overstated. Market will go through price correction in this cycle and the corporate and national economy fundamentals do not seem to support the current prices. Investors become critic about the management actions and evaluate the information about companies and the economy critically. 
Investors are more likely to pay less attention to the true nature of earnings changes in an optimistic market cycle because investors tend to receive the increases in EPS positively and are generally optimistic about management actions and its ambitious business plans. This phenomenon presents an opportunity for earnings management through discretionary accruals. In addition, the market positive trend in an optimistic cycle attracts more unsophisticated and inexperienced investors who are likely to fail to understand the true nature of changes in EPS. This study contributes to the literature by improving our understanding of when investors are likely to identify managed earnings and when they are less likely. Findings from this study should help future researchers as well as financial analysts improve their analysis by controlling the effect of market cycles on investors' use of EPS information and their reaction to earnings management.

This paper continues as follows: section two presents literature review and hypothesis development. Section three describes methodology. Section four presents test results. Section five explains summary and discussion.

\section{LITERATURE REVIEW AND HYPOTHESIS DEVELOPMENT}

Prior studies present evidence of opportunistic earnings manipulation for various situations. A line of research investigated earnings manipulation in the case of equity offering and documented that firms used incomeincreasing accruals before a seasoned equity offering to inflate earnings numbers (e.g Teoh et al., 1998; Rangan 1998; Shivakumar, 2000; Marquardt and Wiedman, 2004; Yongtae and Myung, 2005). Similar pattern was found for the case of initial public offering firms (e.g. Li and McConomy, 2004; Ducharme, Malatesta and Sefcik, 2004) and for the case of stock financial acquisitions (e.g. Erickson and Wang, 1998; Louis, 2004; Heron and Lie, 2002).

Another line of research investigated earnings manipulation in the cases of meeting financial analysts' forecasts. These studies found that management engaged in earnings manipulation to meet the expectations and avoid reporting earnings lower than analysts' expectations (e.g. Burgstahler and Eames, 1998; Cheng and Warfield, 2005, Lacina and Karim, 2004). Similar findings are reported in Abarbanell and Lehavy (1998) that find firms receiving buy recommendations from analysts are more likely to manage their earnings to meet analysts' earnings expectations. Prior studies also presented evidence that firms engaged in earnings management to avoid reporting EPS lower than management earnings forecasts (e.g. Kasznik, 1999; Karamanou and Vafcas, 2005; Ajinkya, Bhojraj and Sengupta, 2005). Burgstahler and Dichev (1997) found that firms manage their reported earnings to avoid earnings decreases and losses. They found that there are unusually lower frequencies of small decreases in earnings and small losses, and unusually higher frequencies of small increases in earnings and small positive income. Degeorge et al. (1999) also found that firms manage their earnings upward which are falling just short of thresholds.

While prior studies present useful insight about the situations in which firms are likely to manage their earnings, there are only few studies that addressed the situation in which a firm's ability to engage in earnings management is restricted. Investigation of factors that restrict the management's ability to engage in earnings management is important because it will help us to understand the process of engaging in earnings management by firms rather than the evidence of earnings management. For example, Marquardt and Wiedman (2004) found that different firms use different accrual items to manage their earnings for different purposes. Also, Barton and Simko (2002) found that earnings management in the following periods is limited by type and extent of use of the accruals which were used in the preceding periods because of the effect of accruals reversion. Detection likelihood is another factor that has been found effective on the management ability to engage in earnings management. Ducharmeet at al. (2004) found that the magnitude of unexpected accruals is positively associated with probability of shareholder litigation against stock issuing firms. Beneish (1999) found that large increases in total accruals were associated with the probability of being the target of SEC enforcement action. Another limiting factor investigated by prior studies is perceived earnings quality (Leuz, Nanda and Wrysocki, 2003). They found that undetected earnings management could impact negatively the perceived earnings quality by shareholders if the earnings management results in higher gap between earnings and cash flow.

Research, however, in the area of the situation in which firms are likely (unlikely) to engage in earnings management is in early step and further studies are needed to explore other factors that may affect the process of engaging in earnings management. The current study contributes to the literature by investigating the effect of stock 
market cycles on the likelihood of engaging in earnings management. The investigation of the effect of market cycles is important as prior studies found that economic conditions such as economic cycles are effective on corporate decision for executive performance evaluation and their compensation structure (e.g. Matolcsy, 2000).

Different market cycles could influence the incentive for engaging in earnings management by affecting shareholders' emotional reaction to earnings changes. In an optimistic market cycle, investors are less likely to investigate the true nature of changes in earnings due to market positive environment and also the existence of naive investors in the market. The market high returns attract many naive investors who may not be able to investigate the true nature of EPS changes. Thus, the likelihood of being detected or questioned about accrual changes is lower in this cycle and consequently the potential cost of earnings management is lower. However, the market environment is different in a neutral cycle and there are no investors' emotional reactions to earnings changes. Investors analyze the management actions analytically, especially for financial reporting policies. In addition, there are fewer naive investors in the market because of lack of large stock returns in the short-time which are usually seen in an optimistic market cycle. In this case, investors are likely to detect the managed portion of earnings and discount it in the prices. On the other hand, a pessimistic market cycle could affect the cost and likelihood of earnings management differently. In a pessimistic cycle investors are critical of management actions, especially financial reporting due to general negative market environment. Thus, investors' reaction to earnings management would be negative, which means investors may reduce the stock price of the firms that report increases in discretionary accruals. In addition, the impact of negative news is higher than the effect of good news in this cycle. According to our discussion, we define the following three hypotheses:

Ha: Increases in discretionary accruals are positively associated with increases in unexpected stock returns in an optimistic market cycle.

Hb: Increases in discretionary accruals are not significantly associated with unexpected stock returns in a neutral market environment.

Hc: Increases in discretionary accruals are associated with negative unexpected stock returns in a pessimistic market environment.

\section{DATA AND METHODOLOGY}

\section{Time Period And Data}

The period of the third quarter of 1998 to the end of the first quarter of 2000 is selected as an optimistic market cycle. In this period, major stock market indexes rose significantly as presented in panel B of Table 1. It shows that the market breath was generally positive and stock prices rose across the board during this period. Dow Jones Industrials (DJI) rose 43\%, NASDAQ rose 259\% and S\&P500 rose 52\%. However, such optimism did not exist in a similar period before and after the optimistic cycle. We selected five quarters before the optimistic cycle as neutral market cycle. During this period, DJI rose only 1.5\%, NASDAQ rose 41\% and S\&P500 rose 14\%, which are consistent with normal market returns (Table 1, Panel A). The NASDAQ increase of $41 \%$ is also normal because this market was hit by a new wave of IPO companies during that period. We chose five quarters after the optimistic cycle as pessimistic cycle. During this period DJI lost 6.4\%, NASAQ lost 55\% and S\&P500 lost 19\% (Table 1, Panel C). The magnetite of the losses indicates that investors became very critic during this period and price corrections started across the board. We used quarterly data because quarterly earnings news has been the most important piece of information for stock price evaluation and it allows us to investigate earnings management on a quarterly basis. 
Table 1

Market Trend During The Period Of January 01, 1999 To March 31, 2000

Panel A: Change in the major indexes during neutral cycle

\begin{tabular}{lcccc} 
Index & July 01, 97 & Sep 30, 98 & Change & of change \\
\hline DJI & 7722 & 7842 & 120 & $1.5 \%$ \\
NASDAQ & 953 & 1345 & 392 & $41 \%$ \\
S\&P 500 & 891 & 1017 & 126 & $14 \%$
\end{tabular}

Panel B: Change in the major indexes during optimistic cycle

\begin{tabular}{lcccc} 
Index & Oct 01,98 & Mar 31, 00 & Change & \% of change \\
\hline DJI & 7632 & 10921 & 3289 & $43 \%$ \\
NASDAQ & 1273 & 4572 & 3299 & $259 \%$ \\
S\&P 500 & 986 & 1498 & 512 & $52 \%$
\end{tabular}

Panel C: Change in the major indexes during pessimistic cycle

\begin{tabular}{lcccc} 
Index & April 03, 00 & June 29, 01 & Change & \% of change \\
\hline DJI & 11221 & 10502 & -719 & $-6.4 \%$ \\
NASDAQ & 4077 & 1832 & -2245 & $-55 \%$ \\
S\&P 500 & 1505 & 1224 & -281 & $-19 \%$ \\
\hline
\end{tabular}

\section{Discretionary Accruals}

Firms may manipulate their earnings in different ways. It can be done by manipulating specific items such as manipulating accounts receivable (Beneish, 1997), bad-debt expense (McNichols and Wilson, 1988) and loan losses (Beaver and Engel (1996). Also, the manipulation can be done using total accruals which are non-cash items and could have increasing or decreasing effect on net income. While first approach investigates how a specific accounting item could be used to manipulate earnings, the second approach investigates the collective effect of accrual items on the reported earnings.

We use the second approach in this paper as our objective is to investigate earnings management in general without referring to a particular item. Accordingly, we calculate total accruals for firm $i$ in quarter $t$ as follows:

$\mathrm{TAC}_{\mathrm{it}}=\left(\Delta \mathrm{CA}_{\mathrm{it}}-\Delta \mathrm{Cash}_{\mathrm{it}}\right)-\left(\Delta \mathrm{CL}_{\mathrm{it}}-\Delta \mathrm{CPL}_{\mathrm{it}}\right)-\mathrm{DEP}_{\mathrm{it}}$

where $\mathrm{TAC}_{\mathrm{it}}$ is total accruals, $\mathrm{CA}_{\mathrm{it}}$ is total current assets, Cash is total cash and equivalent, $\mathrm{CL}_{\mathrm{it}}$ is total current liabilities, $\mathrm{CPL}_{\mathrm{it}}$ is total current portion of long term debt and $\mathrm{DEP}_{\mathrm{it}}$ is depreciation expense. $\Delta$ indicates change in the respective variable.

$\mathrm{TAC}_{\mathrm{it}}$ includes both portions of non-discretionary and discretionary accruals. Accordingly, discretionary accruals are computed as follows:

$\mathrm{DAC}_{\mathrm{it}}=\mathrm{TAC}_{\mathrm{it}}-\mathrm{NDAC}_{\mathrm{it}}$

Where $\mathrm{DAC}_{\mathrm{it}}$ is discretionary accruals for firm i in quarter $\mathrm{t}$ and $\mathrm{TAC}_{\mathrm{it}}$ is total accruals reported by firm $i$ in the same quarter. $\mathrm{NDAC}_{\mathrm{it}}$ is non-discretionary accruals.

In the absence of earnings management, the mean of $\mathrm{DAC}_{\mathrm{it}}$ should be zero during this test period. A nonzero and positive mean of discretionary accruals indicates the use of accruals to overstate earnings. Nondiscretionary accruals are estimated using modified Jones model. This model has been found more appropriate than 
other existing models in capturing non-discretionary accruals (Dechow et al., 1995). We used the following model to estimate non-discretionary accruals:

$\operatorname{NDAC}_{\mathrm{it}} / \mathrm{TA}_{\mathrm{i}, \mathrm{t}-1}=\beta_{1}\left(1 / \mathrm{TA}_{\mathrm{i}, \mathrm{t}-1}\right)+\beta_{2}\left(\mathrm{NREV}_{\mathrm{i}, \mathrm{t}} / \mathrm{TA}_{\mathrm{it}-1}\right)+\beta_{3}\left(\mathrm{PPE}_{\mathrm{it}} / \mathrm{TA}_{\mathrm{i}, \mathrm{t}-1}\right)$

where NDAC $\mathrm{Cit}_{\mathrm{it}}$ non-discretionary accruals, $\mathrm{TA}_{\mathrm{i}, \mathrm{t}-1}$ is total assets, $\mathrm{NREV}_{\mathrm{i}, \mathrm{t}}$ is total revenue net of receivables, $\mathrm{PPE}_{\mathrm{i}, \mathrm{t}}$ is total plant, property and equipment and $\beta$ is the respective coefficient. The model parameters, $\beta 1, \beta 2$ and $\beta 3$, are estimated using an OLS regression.

\section{Sample Selection}

Initial samples were obtained from Compustat. We required that firms must have at least 25 necessary data to compute model 3 for the period of the first quarter of 1990 to the end of the third quarter of 1998 . This procedure resulted in a sample of 1509 firms. Table 3 presents the breakdown of the sample based on industry membership and Table 4 summarizes the descriptive statistics for the sample.

Table 2

Industry Classification Of Sample Firms

\begin{tabular}{lc} 
& Number of Firms \\
& \\
Basic Industries & 115 \\
Capital Goods & 385 \\
Construction & 44 \\
Consumer Goods & 813 \\
Energy & 110 \\
Finance & 42 \\
\hline Total & 1509 \\
& $====$
\end{tabular}

The following approach is used to classify the samples into the different industries:

Basic Industries:

Capital Goods:

Construction:

Consumer Goods:

Energy:

Finance:
1000-1299, 1400-1499, 2600-2699, 2800-2829, 2870- 2899, 3300-3399.

$3400-3419,3440-3599,3620-3629,3670-3699,3800-3849,5080-5089$, 5100-5129, 5160-5169, 7300-7399.

1500-1999, 2400-2499, 3220-3299, 3430-3439, 5200-5219.

0000-0999, 2000-2399, 2500-2599, 2700-2799, 2830-2869, 3000-3219, 3420-3429, $3600-3619$, 3630-3669, 3700-3719, 3850-3899, 3900-3999, 4830-4899, 5000-5079, 5090-5099, 5130-5159, 5180-5199, 5220-5999, 7000-7299, 7400-9999. 1300-1399, 2900-2999, 5170-5179.

6000-6999.

Table 3

Descriptive Statistics

Panel A: Breakdown of discretionary accruals by period:

\begin{tabular}{|c|c|c|}
\hline Market cycle & Mean & $\underline{\mathrm{SD}}$ \\
\hline Neutral & .0202 & 1.212 \\
\hline Optimistic & .0595 & 1.239 \\
\hline Pessimistic & -.0121 & .374 \\
\hline
\end{tabular}


Table 2 shows that the sample is distributed across industries considering the size of each industry. Table 3 shows that the means of discretionary accruals. The negative mean in the pessimistic cycle indicates the mean reversion of accruals.

\section{Hypothesis Testing}

We use the following model to test the hypotheses:

$\mathrm{AR}_{\mathrm{it}}=\beta_{0}+\beta_{1} \mathrm{DTAC}_{\mathrm{it}}$

where $\mathrm{AR}_{\mathrm{it}}$ is unexpected stock returns and $\mathrm{DTAC}_{\mathrm{it}}$ is discretionary accruals.

Investors' reaction to charges in discretionary accruals in each market cycle is tested as follows:

If $\beta_{1}=0$ no investors' reaction

If $\beta_{1}>0$ positive reaction

If $\beta_{1}<0$ negative reaction

We calculated unexpected stock returns using the market model and used S\&P 500 as the market proxy.

\section{TEST RESULTS}

The test results are presented in Table 4 .

Table 4

Regression Test Results

\begin{tabular}{lrrrr}
\hline Market Cycles & $\underline{\underline{\beta}_{0}}$ & $\frac{\mathrm{t}-\mathrm{value}}{8.450}$ & .157 & $\underline{\mathrm{t}-\mathrm{value}}$ \\
Neutral & 1.76 & .917 \\
Optimistic & 2.033 & 11.118 & .148 & 2.864 \\
Pessimistic & .913 & 4.143 & -.971 & -1.650 \\
\hline
\end{tabular}

Table 4 shows that $\beta_{1}$ is insignificant for the neutral cycle which indicates that increases in discretionary accruals were not associated with higher unexpected stock returns. These findings present support for hypothesis one and suggest that investors detected abnormal changes in discretionary accruals and discounted them in the stock prices. Table 4 shows that the coefficient is positive and significant for the optimistic cycle indicating that increases in discretionary accruals were associated with higher unexpected stock returns. The findings present support for hypothesis two and indicate that investors did not pay attention to the true nature of earnings changes in the optimistic cycle. Table 4 also presents test results for pessimistic cycle. The coefficient is negative, but weakly significant, indicating although the sign of the coefficient presents support for hypothesis three, we do not find strong support for this hypothesis.

\section{Industry Effect}

In this section, we focus on optimistic cycle for which we found strong positive association between increases in discretionary accruals and stock returns, and test whether the industry membership was effective. Such an investigation will indicate whether industry membership was a significant factor in engaging in managing earnings in the optimistic cycle. This investigation is also beneficial as the degree of optimistic market environment can be different for different industries. To test the industry effect, we compute the following metric for each industry: 


$$
\overline{D A C_{I N D}}=\sum D A C_{i, I N D} / n_{I N D}
$$

where $\overline{D A C_{I N D}}$ is the mean of discretionary accruals for each industry, $\mathrm{DAC}_{\mathrm{i}, \mathrm{IND}}$ is discretionary accruals for firm I in each industry, and $\mathrm{n}_{\mathrm{IND}}$ is number of the firms in each industry.

The test results are presented in table 5 .

Table 5

Earnings Management And Industry Membership

\begin{tabular}{|c|c|c|c|c|}
\hline Industry & $\underline{\text { Samples }}$ & $\overline{D A C_{I N D}}$ & $\underline{T \text {-value }}$ & Sig. \\
\hline Basic Industries & 115 & 1.149 & 1.086 & .280 \\
\hline Capital Goods & 385 & .073 & 3.537 & .000 \\
\hline Construction & 44 & .052 & 3.418 & .001 \\
\hline Consumer Goods & 813 & .178 & 1.810 & .071 \\
\hline Energy & 110 & .137 & 3.413 & .001 \\
\hline Finance & $\underline{42}$ & 8.372 & 1.553 & .128 \\
\hline
\end{tabular}

Table 5 indicates that the discretionary accruals means are significant for four industries (capital goods, construction, consumer goods, and energy), except consumer goods which is significant at .1 level. However, the mean is not significant for basic industries and finance. The findings show that earnings management was not observed across industries alike. These findings suggest that market optimism may exist only in certain industries and that provides incentive for earnings management.

\section{SUMMARY AND CONCLUSION}

This paper presents evidence about the effect of stock market cycles on the association between earnings management and stock price returns. It shows when the stock market turns to an optimistic cycle, investors are affected by the general optimistic market environment and tend to ignore the nature of changes in earnings. In such an environment, investors are more receptive of the management ambitious business actions which may results in higher accruals. This situation presents ground for likelihood of engaging in earnings management. In addition, the market high performance in an optimistic cycle attracts more naive investors who may not be able to analyze the nature of changes in EPS and distinguish between discretionary and non-discretionary accruals. Our results show that one dollar increase in discretionary accruals resulted in fifteen cents increase in stock price return on average in the optimistic market cycle. On the other hand, our results show that investors were able to identify the effect of discretionary accruals on EPS changes in the neutral market environment and discount that effect in the stock prices. The test results showed that there was no association between increases in discretionary accruals and increases in stock prices in the neutral cycle. This could be due to lack of emotional decision making in this cycle and the existence of fewer naive investors in the market. On the other hand, our test results showed that investors may react negatively to increases in discretionary accruals in a pessimistic cycle. We found a negative relationship between increases in discretionary accruals and stock prices in that cycle. These findings suggest that when the market environment is generally negative, boosting EPS by increasing discretionary accruals will have a negative effect of investors' valuation of stock prices. Our test results also show that the association between increases in discretionary accruals and increases in stock returns was not the same in different industries. This suggests that the optimistic cycle could be driven by factors which affect only certain industries.

This study contributes to the growing literature on what factors may limit the firm's ability to engage in earnings management. The findings presented in this study will help us to understand the process of engaging in 
earnings management and the effect of market cycle on this process. Also, the results presented in this study may help researchers and financial analysts to understand the true nature of ratios such as P/E (price to EPS) and P/B (price to book value) in different market cycles. Our findings suggest that the time series analysis of P/E and P/B ratios without proper adjustment for the effect of market cycles on discretionary accruals may be biased and misleading.

This study is limited in some aspects. We selected firms that had sufficient data in Compustat files. Although our sample is fairly large for statistical analyses, the effects of firms which are not listed in Compustat or did not have sufficient data are excluded. We also selected the total of fifteen quarters as optimistic, neutral and pessimistic cycles. Although those quarters reflected dramatic shifts in the selected time period which fairly represent the market cycles, the effect of larger cycles may or may not be consistent with our results. Also, we use the data the U.S. stock markets, which may or may not represent the effect of market cycles in other courtiers. These limitations present opportunities for future studies to extent this study.

\section{REFERENCES}

1. Abarbanell, J. and R. Lehavy. 2003. Biased Forecasts or biased earnings? The role of reported earnings in explaining apparent bias and over/under-reaction in analysts' earning forecast. Journal of Accounting and Economics 36: 105.

2. Abarbanell, J. and R. Lehavy. 2003. Can Stock Recommendations Predict Earnings Management and analysts' earnings forecast errors? Journal of Accounting Research 41: 1-31.

3. Aharony, J., C. J. Lee. and T. J. Wong. 2000. Financial Packaging of IPO firms in China. Journal of Accounting Research 38: 103-126.

4. Ajinkya, B., S. Bhojraj. and P. Sengupta . 2005. The Association Between Outside Directors, Institutional Investors and Properties of Management Earnings Forecast. Journal of Accounting Research 43: 343.

5. Barton, J. and P. Simko. 2002. The Balance Sheet as an Earnings Management Constraint. The Accounting Review 77: 1-27.

6. Beaver, W. and E. Engel. 1996. Discretionary Behavior With Respect to Allowances for Loan Losses and the Behavior of Security Prices. Journal of Accounting and Economics 22: 177.

7. Beneish, M. 1997. Detecting GAAP Violation : Implications for Assessing Earnings Management among Firms with Extreme Financial Performance. Journal of Accounting and Public Policy 16: 271.

8. Beneish, M. 1999. The Detection of Earnings Manipulation. Financial Analysis Journal 55: 24-36.

9. Beneish, M. 1999. Anote on Wiedman's Instructional case : Detecting Earnings Manipulation. Issues in Accounting Education 14: 369-370.

10. Burgstahler, D. and I. Dichev. 1997. Earnings management to avoid earnings decreases and losses. Journal of Accounting and Economics 24: 99-126.

11. Burgstahler, D. and M. Eames. 1998. Management of earnings and analysts forecasts. Working paper, University of Washington.

12. Cheng, Q. and T. Warfield. 2005. Equity Incentives and Earnings Management. The Accounting Review 80: 441-476.

13. Ducharme, L., P. Malatesta, S. Sefcik. Earning Management, Stock Issues, and ShareHolder Lawsuits . Journal of Financial Economics 71: 27.

14. Degeorge, F., J. Patel and R. Zeckhauser. 1999. Earnings Management to Exceed Thresholds. The Journal of Business 72: 1-33.

15. Erickson, M. and S-w. Wang. 1999. Earnings Management by Acquiring Firms in Stock for Stock Merger. Journal of Accounting and Economics 27: 149-176.

16. Fischer, P. and P. Stocken. 2004. Effect of Investor Speculation on Earning Management. Journal of Accounting Research 42: 843.

17. Heron, R. and E. Lie. 2002. Operating Performance and the Method of Payment in TakeOver. Journal of Financial and Quantitative Analysis 37: 137-155.

18. Karamanou, I. and N. Vafeas. 2005. The Association Between Corporate Boards, Audit Committees, and Management Earnings Forecasts: An Empirical Analysis. Journal of Accounting Research 43: 453.

19. Kasznik, R. 1999. On the Association Between Voluntary Disclosure and Earnings Management. Journal of Accounting Research 37: 57-81. 
20. Leuz, C., D. Nanda. And P. Wysocki. 2003. Earnings Management and Investor Protection: an International Comparison. Journal of Financial Economics 69: 505.

21. LI, Y. and B. McConomy. 2004. Simultaneous Signaling in IPOs via Management Earnings Forecasts and Retained Ownership: An Empirical Analysis of the Substitution Effect. Journal of Accounting, Auditing and Finance 19: 1.

22. Lacina, M. and K. Karim. 2004. Tests of Market Reaction and Analysts' Forecast Revisions to Disclosure of Improved Management Earnings Expectations: A Case of Concurrent Bad News Management Earnings Forecasts. Review of Quantitative Finance and Accounting 23: 123.

23. Louis, H. Earnings Management and the Market Performance of Acquiring Firms. Journal of Financial Economics 74:121.

24. Marquardt, C. and C. Wiedman. 2004. The Effect of Earning Management on the Value Relevance of Accounting Information. Journal of Business Finance \& Accounting 31: 297-332.

25. Marquardt, C. and C. Wiedman. 2004. How are Earnings Managed? An Examination of Specific Accruals. Contemporary Accounting Research 21: 461-489.

26. Matolcsy, Z. 2000. Executive Cash Compensation and Corporate Performance During Different Economic Cycles. Contemporary Accounting Research 17: 671-692.

27. McNichols, M., P. Wilson. and D. Linda. 1988. Evidence of Earnings Management from the Provision for Bad Debts;Discussion. Journal of Accounting Research 26: 1-40.

28. Rangan, S. 1998. Earnings Before Seasoned Equity Offerings: are They Overstated? Journal of Financial Economics 50: 101-122.

29. Shivakumar, L. 2000. Do Firms Mislead Investors by Overstating Earnings Before Seasoned Equity Offering?. Journal of Accounting and Economics 29: 339-371.

30. Teoh, S. T., 1. Welch. and T. J. Wong. 1998. Earnings Management and the Post- Issue Performance of Seasoned Equity Offerings. Journal of Financial Economics 50: 63-99.

31. Yongtae, K. and S.P.Myung. 2005. Pricing of Seasoned Equity Offers and Earning Management. Journal of Financial and Quantitative Analysis 40: 435. 
NOTES 